\title{
CHANGES IN CARBOHYDRATE CONTENTS IN TABLE POTATO TUBERS UNDER THE INFLUENCE OF SOIL CONDITIONER UGMAX
}

\author{
ZARZECKA, K. * - GUgAŁA, M. - GRZYWACZ, K. - DOMAŃSKI, Ł. \\ Department of Agrotechnology, Siedlce University of Natural Sciences and Humanities \\ Prusa 14, 08-110 Siedlce, Poland \\ (e-mail:kzarzecka@uph.edu.pl,gugala@uph.edu.pl,kornelia.grzywacz@wp.pl, \\ domanski1403@gmail.com) \\ *Corresponding author \\ e-mail: kzarzecka@uph.edu.pl
}

(Received $31^{\text {st }}$ Oct 2018; accepted $11^{\text {th }}$ Jan 2019)

\begin{abstract}
The content of total sugars and reducing sugars in potato tubers is one of the most important quality features determining the suitability for direct consumption and for processing into food products. The objective of the study was to determine the effect of the soil conditioner UGmax on total sugars, reducing (simple) sugars and sucrose in potato tubers. Experimental material consisted of tubers of second early table potato grown in a field experiment conducted in central-eastern Poland. Following chemical analyses, statistical calculations were performed and they demonstrated a significant effect - an application of the soil conditioner UGmax contributed to an increase in the tuber content of reducing sugars compared with control potato tubers. The highest simple sugar content was found after three applications of the soil conditioner at the rate of 1.0 and $2.0 \mathrm{dm}^{3} \mathrm{ha}^{-1}$. The remaining carbohydrates determined in the study did not respond to UGmax application. Cultivars grown in the study differed significantly in terms of reducing sugar content only, more sugars being accumulated by Tajfun rather than Satina.
\end{abstract}

Keywords: cultivars, reducing sugars, Solanum tuberosum, sucrose, total sugars

\section{Introduction}

Plant production intensification and specialisation, which have led to reduced soil tillage, monoculture, intensive chemical protection, use of heavy machines/tools, shortage of natural manures, result in worsened physical, chemical and microbiological soil properties as well as limited availability of nutrients for plants (Malero et al., 2006). Soil environment is impoverished and lower yields are often produced. Due to this, the need arises to reduce the unfavourable influence and seek eco-friendly solutions. The idea of environment and consumer protection is becoming increasingly popular and seems to become a necessity (Mrówczyński and Roth, 2009). The soil conditioner UGmax, produced by 'Bogdan' Trade-Service Co, Ltd., is a microbiological product available on the Polish market and recommended for application in crop cultivation. It is an extract obtained from a special compost and used to enhance soil fertility. Microorganisms contained in the conditioner boost soil biological activity, increase the solubility of mineral compounds which plants find difficult to take up and promote humus formation (Trawczyński and Bogdanowicz, 2007; Dębska et al., 2016). It results in beneficial changes in soil physical and water status-related properties, $\mathrm{pH}$ and structure as well as better rooting system development (Kaczmarek et al., 2008; Piotrowska et al., 2012; Dębska et al., 2016) and, in consequence, increased higher 
quality yields of crops (Dinesh et al., 2010; Kołodziejczyk, 2014; Pobereżny et al., 2015; Kowalska, 2016).

Potato is one of major agricultural plants which is a staple food for people worldwide and a crop which is classified as one of key plants responsible for maintaining food security. Potato is consumed fresh or processed in both developing and developed countries (Camire et al., 2009; Lisińska et al., 2009; King and Slavin, 2013). Potato tubers are highly nutritious as they contain plenty of starch, protein characterised by high dietetic value, vitamin $\mathrm{C}, \mathrm{B}_{3}, \mathrm{~B}_{6}$, minerals, in particular potassium, phosphorus, magnesium and iron. The crop is also a valuable source of health-promoting compounds such as dietary fibre, phenols and carotenoids (Slavin, 2013; Andre et al., 2014). Tuber chemical components are cultivar-related but are also affected by agronomic practices, water availability and thermal conditions (Abong et al., 2009; Grudzińska et al., 2014; Ozturk and Polat, 2016). As it has been suggested that plant protection products, fertilisers, biostimulants and microbiological products may cause changes in plant chemical composition, studies have been undertaken to check their effect on the nutritional value of agricultural produce (Sawicka and Pszczółkowski, 2005; Gugała et al., 2013). Hence the present study aimed at determining the effect of the soil conditioner UGmax on total sugars, reducing sugars and sucrose in table potato tubers.

\section{Materials and methods}

\section{Experimental and Agronomic Management}

Research results were obtained from a three-year field experiment conducted at the Zawady Experimental Farm of Siedlce University of Natural Sciences and Humanities $\left(52^{\circ} 03^{\prime} \mathrm{N}\right.$; $22^{\circ} 33^{\prime}$, central-eastern Poland) on a soil classified as Luvisol, whose pH ranged from slightly acidic to acidic $(4.81-5.91 \mathrm{pH}$ in $\mathrm{KCl})$ and which was characterised by a high to very high available phosphorus content, moderate to high potassium content and low magnesium content (Table 1) (Marcinek and Komisarek, 2011). The experiment was set up as a split-plot arrangement with three replicates.

Table 1. Selected chemical properties of soil on which the experiment was conducted

\begin{tabular}{c|c|c|c|c|c}
\hline \multirow{2}{*}{$\begin{array}{c}\text { Study } \\
\text { years }\end{array}$} & \multirow{2}{*}{$\begin{array}{c}\text { Acidity } \\
(\mathbf{p H} \text { in KCl) }\end{array}$} & \multirow{2}{*}{$\begin{array}{c}\text { Organic matter } \\
\left(\mathbf{g ~ k g}^{-1}\right)\end{array}$} & \multicolumn{3}{|c}{$\begin{array}{c}\text { Available nutrients } \\
\left(\mathbf{m g ~ k g}^{-1} \mathbf{s o i l}\right)\end{array}$} \\
\cline { 4 - 6 } & & & $\mathbf{P}$ & $\mathbf{K}$ & $\mathbf{M g}$ \\
\hline 2008 & 4.99 & 15.4 & 90.64 & 124.5 & 41.0 \\
2009 & 4.81 & 16.8 & 76.12 & 173.4 & 34.0 \\
2010 & 5.91 & 18.1 & 73.48 & 112.1 & 45.0 \\
\hline
\end{tabular}

The first factor was two mid-early cultivars of table potato - Satina and Tajfun (Table 2).

Table 2. Description of potato cultivars used in the study

\begin{tabular}{c|c|c|c|c|c}
\hline Cultivars & $\begin{array}{c}\text { Registration } \\
\text { year }\end{array}$ & Origin & Maturity & $\begin{array}{c}\text { Yield } \\
\left(\mathbf{t ~ h a}^{-\mathbf{1}}\right)\end{array}$ & Utilization \\
\hline Satina & 2000 & Germany & second early & 43.9 & $\begin{array}{c}\text { canned, frozen, } \\
\text { salads, boiled }\end{array}$ \\
\hline Tajfun & 2004 & Poland & second early & 49.8 & boiled \\
\hline
\end{tabular}


The second factor was five methods of an application of the soil conditioner UGmax:

1. Control object - without the use of UGmax spraying with water.

2. UGmax - application before planting, at a dose of $1.0 \mathrm{dm}^{3} \cdot \mathrm{ha}^{-1}$.

3. UGmax - application before planting, at a dose of $0.5 \mathrm{dm}^{3} \cdot \mathrm{ha}^{-1}$ and double foliar application (10-15 cm potato plant height) at a dose $0.25 \mathrm{dm}^{3} \cdot \mathrm{ha}^{-1}$, (flowering) at a dose $0.25 \mathrm{dm}^{3} \cdot \mathrm{ha}^{-1}$.

4. UGmax - application before planting, at a dose of $1.0 \mathrm{dm}^{3} \cdot \mathrm{ha}^{-1}$ and double foliar application $\left(10-15 \mathrm{~cm}\right.$ potato plant height) at a dose $0.5 \mathrm{dm}^{3} \cdot \mathrm{ha}^{-1}$, (flowering) and at a dose $0.5 \mathrm{dm}^{3} \cdot \mathrm{ha}^{-1}$.

5. UGmax - double foliar application $(10-15 \mathrm{~cm}$ potato plant height) at a dose 0.5 $\mathrm{dm}^{3} \cdot \mathrm{ha}^{-1}$, (flowering) and at a dose $0.5 \mathrm{dm}^{3} \cdot \mathrm{ha}^{-1}$.

The conditioner contained: lactic acid bacteria, photosynthetic bacteria, Azotobacter, Pseudomonas, yeast, actinomycetes as well as the following amounts (mg l) of macroelements and microelements: potassium -2905 , nitrogen -1200 , sulphur -1000 , phosphorus -220 , sodium -200 , magnesium -100 , zinc -20 , manganese $-0.3-$ produced by Bogdan, Trade-Service Co., Poland (Trawczyński, 2007; Zarzecka and Gugała, 2013). Farmyard manure was applied at a rate of $25.0 \mathrm{t} \mathrm{ha}^{-1}$ in addition to mineral fertilisers used at the following rates: $44.0 \mathrm{~kg} \mathrm{ha}^{-1} \mathrm{P}$ (in the form of $46 \%$ triple superphosphate - Group Azoty Chemical Establishments Police SA, Poland), $124.5 \mathrm{~kg}$ $\mathrm{ha}^{-1} \mathrm{~K}$ (in the form of $60 \%$ potassium salt - Establishments Trading Commodities Siarkopol Sp. z o.o. Tarnobrzeg, Poland) and $100 \mathrm{~kg} \mathrm{~N}$ per 1 ha (in the form of 34\% ammonium salt - Group Azoty Nitrogen Establishments Pulawy SA, Poland) applied in spring. Potatoes were planted at the spacing of $0.675 \times 0.370 \mathrm{~m}$ in mid-April and harvested at physiological maturity in the first half of September. Weeds were controlled by means of a mixture herbicides: chlomazon (Command 480 SC - FMC Chemical sprl, Belgium) at a dose of $0.2 \mathrm{dm}^{3} \mathrm{ha}^{-1}$ and linuron (Afalon Dispersive 450 SC - Agan Chemical Manufactures Ltd., Israel) at a dose of $1.0 \mathrm{dm}^{3} \mathrm{ha}^{-1}$ applied 5-7 days prior to potato plant emergence. During the period of crop growth and development, potato blight was controlled using fungicides: metalaksyl-M 3.8\% and mankozeb 64\% (Ridomil Gold MZ 68 WG - Syngenta Crop Protection AG, Switzerland) - $2.0 \mathrm{~kg} \mathrm{ha}^{-1}$ and mankozeb (Dithane $455 \mathrm{SC}$ - Indofil Industries Limited, Republic of India) - $3.0 \mathrm{dm}^{3} \mathrm{ha}^{-1}$, and Colorado potato beetle was controlled using insecticides: chlotianidyna (Apacz 50 WG - Sumitomo Chemical Takeda Agro Co., Japan) at a dose $0.04 \mathrm{~kg} \mathrm{ha}^{-1}$ and tiametoksam (Actara $25 \mathrm{WG}$ - Syngenta Crop Protection AG, Switzerland) at a dose $0.08 \mathrm{~kg} \mathrm{ha}^{-1}$.

\section{Determination of carbohydrates}

Before harvest, tuber samples from 10 plants per plot were collected in all experimental units and used for chemical analyses. The analyses were carried out each year in triplicate, representing a total of 90 samples. Total sugars and reducing sugars were determined after harvest in the fresh matter of unpeeled potato tubers by means of the Schoorl-Luff method (Krełowska-Kułas, 1993). The method involves reduction, under alkaline conditions, of copper sulphate by reducing sugars contained in Luff solution at the boiling temperature. Basic solution (hydrolysate) was prepared. $12.5 \mathrm{~g}$ of potato tubers were grated, made up with water and boiled for 3 minutes. After cooling, the solution was transferred to a $300 \mathrm{ml}$ flask and $5 \mathrm{ml}$ potassium ferrocyanide as well as $5 \mathrm{ml}$ aluminium sulphate were added. After stirring, filtration was performed using a soft filter. 
Total sugars were determined by Schoorl-Luff method. $25 \mathrm{ml}$ of hydrolysate was placed in a $300 \mathrm{ml}$ flask, $2.5 \mathrm{ml}$ of concentrated $\mathrm{HCl}$ was added and the mixture was heated for 5 minutes at $68-72^{\circ} \mathrm{C}$ (hydrolysis of sugars to simple sugars occurred). The solution was cooled and, after adding potassium hydroxide $\mathrm{KOH}$ until constant $\mathrm{pH}$ was obtained in the presence of phenolphthalein, made up to $25 \mathrm{ml}$. Next, $12.5 \mathrm{ml}$ Luff solution was added and followed by $12.5 \mathrm{ml}$ hydrolysate, $25 \mathrm{ml}$ acetic acid, 12.5 iodine solution and $27.5 \mathrm{ml}$ hydrochloric acid. Then, the excessive iodine was titration titrated using sodium thiosulfate until light blue colour was obtained.

Determination of reducing sugars was performed by Schoorl-Luff method. $12.5 \mathrm{ml}$ Luff solution and $12.5 \mathrm{ml}$ hydrolysate were transferred to a $300 \mathrm{ml}$ flack (no hydrolysis was conducted). Then, the procedure was the same as for total sugars.

Sucrose content was calculated by subtracting reducing sugars from total sugars after hydrolysis $\mathrm{x}$ 0.95. Analyses were performed at the Chemical Laboratory of the Department of Agrotechnology, Siedlce University of Natural Sciences and Humanities in Siedlce.

\section{Statistical analysis}

The results of the study were subjected to statistical analysis using the analysis of variance, and the significance of differences was assessed using Tukey test at the significance level of $P=0.05$. Statistical calculations were performed in Excel using the authors' own algorithm based on the split-plot mathematical model.

\section{Weather conditions}

Weather conditions in individual study years, presented in Figure 1 and Table 3, varied. Precipitation was the highest in 2010 when it was higher than the long-term sum by as much as $144.8 \mathrm{~mm}$. The lowest rainfall was in 2009 when it was also unevenly distributed throughout the individual months of the growing season. By contrast, the year 2008 saw the most favourable rainfall pattern whereas 2010 was the warmest. The remaining growing seasons had temperatures similar to the long-term mean.

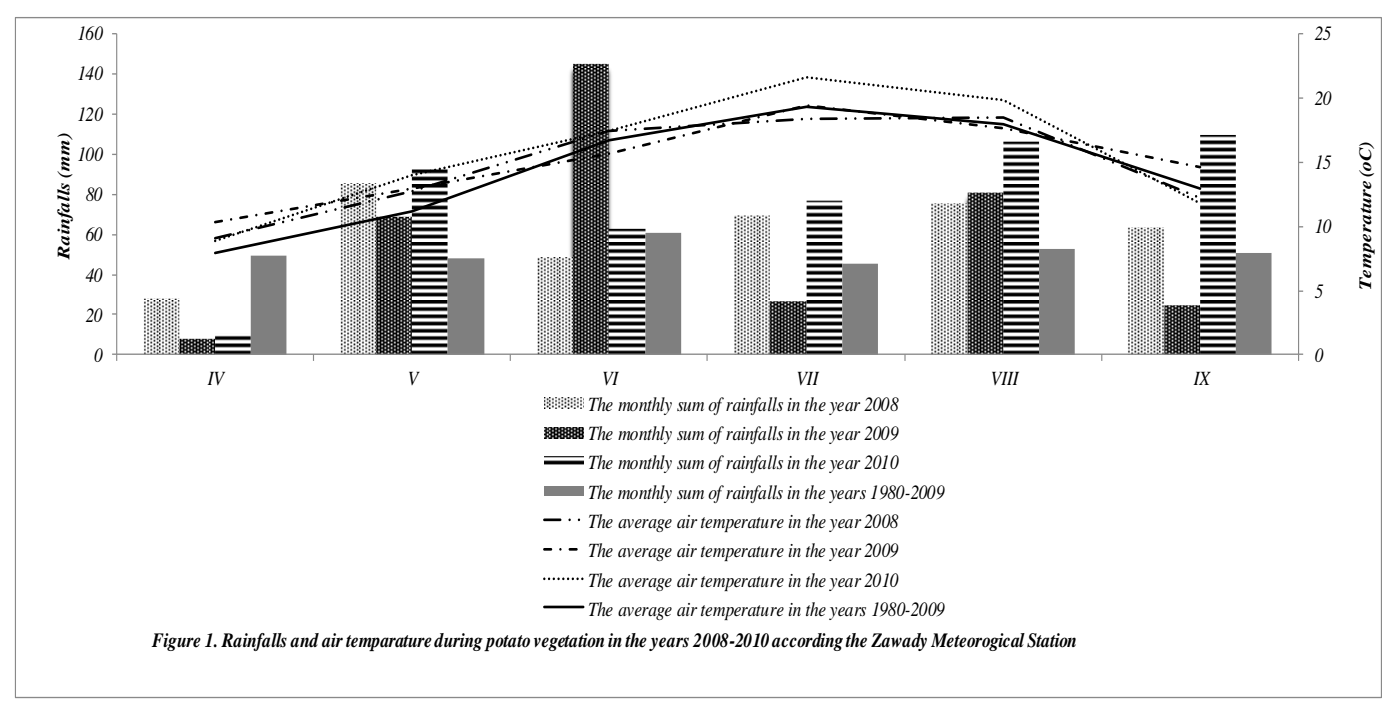

Figure 1. Rainfalls and air temparature during potato vegetation in the years 2008-2010 according the Zawady Meteorogical Station 
Table 3. Climatic conditions during the growing seasons according to the Zawady Meteorological Station

\begin{tabular}{|c|c|c|c|c|c|c|c|}
\hline \multirow{3}{*}{ Study years } & \multicolumn{7}{|c|}{ Deviations from the long-term (1980-2009) mean } \\
\hline & \multicolumn{7}{|c|}{ Total rainfall $(\mathrm{mm})$} \\
\hline & IV & $\mathbf{V}$ & VI & VII & VIII & IX & IV-IX \\
\hline 2008 & -21.4 & +37.4 & -11.7 & +24.1 & +22.4 & +12.7 & +56.5 \\
\hline 2009 & -41.5 & +20.7 & +84.5 & -19.3 & +27.9 & -25.8 & +39.5 \\
\hline \multirow[t]{3}{*}{2010} & -38.9 & +45.0 & +1.9 & +31.3 & +53.3 & +59.2 & +144.8 \\
\hline & \multicolumn{7}{|c|}{ Air temperature $\left({ }^{\circ} \mathrm{C}\right)$} \\
\hline & IV & $\mathbf{V}$ & VI & VII & VIII & IX & IV-IX \\
\hline 2008 & +1.2 & +1052 & +0.7 & -0.9 & +0.5 & -0.8 & +0.3 \\
\hline 2009 & +2.4 & +1.7 & -1.0 & +0.1 & -0.3 & +1.6 & +0.7 \\
\hline 2010 & +1.0 & +2.8 & +0.7 & +2.3 & +1.8 & -1.2 & +1.2 \\
\hline
\end{tabular}

\section{Results}

\section{Total sugars}

Statistical analysis of the obtained results demonstrated that total sugar content was significantly affected by the weather conditions throughout the study years (Tables 4, 5).

Table 4. Total sugars content in potato tubers depending on UGmax and cultivars ( $g \mathrm{~kg}^{-1}$ fresh matter) (mean of years)

\begin{tabular}{l|c|c|c|c}
\multicolumn{1}{c|}{ Treatments (I) } & \multirow{2}{*}{$\begin{array}{c}\text { Doses } \\
\left(\mathbf{d m}^{\mathbf{3}} \mathbf{h a}^{-\mathbf{1}}\right)\end{array}$} & \multicolumn{2}{|c|}{ Cultivars (II) } & \multirow{2}{*}{ Mean } \\
\cline { 3 - 4 } & - & Satina & Tajfun & \\
\hline 1. Control - without UGmax & 1.0 & 6.54 & 6.50 & 6.52 \\
2. UGmax - before planting & 1.0 & 6.55 & 6.59 & 6.57 \\
3. UGmax - before planting and double foliar & & 6.57 & 6.60 & 6.57 \\
$\quad \begin{array}{l}\text { application } \\
\text { 4. UGmax - before planting and double foliar }\end{array}$ & 2.0 & 6.61 & 6.64 & 6.63 \\
$\quad$ application & 1.0 & 6.54 & 6.56 & 6.55 \\
5. UGmax - double foliar treatment & & 6.56 & 6.57 & 6.57 \\
\hline
\end{tabular}

LSD at: 0.05 for: treatments $(\mathrm{I})=\mathrm{ns}$; cultivars $(\mathrm{II})=\mathrm{ns}$; interaction $(\mathrm{I} \times \mathrm{x}$ II $)=\mathrm{ns}$ ns - not significant

Table 5. Total sugars content in potato tubers depending on UGmax and weather conditions ( $\mathrm{kg}^{-1}$ fresh matter) (mean of cultivars)

\begin{tabular}{l|c|c|c|c|c}
\multicolumn{1}{c|}{ Treatments (I) } & \multirow{2}{*}{$\begin{array}{c}\text { Doses } \\
\left(\mathbf{d m}^{\mathbf{3}} \mathbf{h a}^{-\mathbf{1}}\right)\end{array}$} & \multicolumn{3}{|c|}{ Years (III) } & \multirow{2}{*}{ Mean } \\
\cline { 3 - 5 } & - & $\mathbf{2 0 0 8}$ & $\mathbf{2 0 0 9}$ & $\mathbf{2 0 1 0}$ & \\
\hline 1. Control - without UGmax & 1.0 & 6.46 & 6.22 & 6.88 & 6.52 \\
2. UGmax - before planting & 1.0 & 6.49 & 6.25 & 6.98 & 6.57 \\
3. UGmax - before planting and double & & 6.49 & 6.25 & 7.01 & 6.59 \\
$\quad$ foliar application & 2.0 & 6.50 & 6.29 & 7.09 & 6.63 \\
4. UGmax - before planting and double & 1.0 & 6.47 & 6.23 & 6.96 & 6.55 \\
$\quad$ foliar application & & $6.48 \mathrm{~b}$ & $6.25 \mathrm{~b}$ & $6.98 \mathrm{a}$ & 6.57 \\
5. UGmax - double foliar treatment & &
\end{tabular}

LSD at: 0.05 for: treatments $(\mathrm{I})=\mathrm{ns}$; years $(\mathrm{III})=0.31$; interaction $(\mathrm{I} \times \mathrm{III})=\mathrm{ns}$

ns - not significant 
It averaged $6.57 \mathrm{~g} \mathrm{~kg}^{-1}$ fresh matter $(0.657 \%)$, the value being lower than $1 \%$, which is favourable from the standpoint of consumers. The accumulation of total sugars was the smallestt in tubers harvested in $2009\left(6.25 \mathrm{~g} \mathrm{~kg}^{-1}\right)$ which was optimal in terms of hydrological conditions. In 2008, total sugar content was slightly but insignificantly higher compared with the 2009 growing season. An accumulation of total sugars was the highest in the wet and the warmest 2010 , on average $6.98 \mathrm{~g} \mathrm{~kg}^{-1}$, the differences being significantly higher compared with tubers harvested in 2008 and 2009. The cultivars grown in this experiment contained similar amounts of total sugars. In the study described here, a tendency was observed for tubers harvested from UGmaxtreated plots to slightly increase total sugars. However, the values were very small and ranged from 0.03 to $0.05 \mathrm{~g} \mathrm{~kg}^{-1}$.

\section{Reducing sugars}

In the present study, reducing sugars content ranged from $3.41-3.90 \mathrm{~g} \mathrm{~kg}^{-1}$ fresh matter and were significantly affected by cultivars, an application of the soil conditioner UGmax and weather conditions during the study years (Tables 6, 7).

Table 6. Reducing sugars content in potato tubers depending on UGmax and cultivars ( $\mathrm{g} \mathrm{kg}^{-1}$ fresh matter) (mean of years)

\begin{tabular}{l|c|c|c|c}
\hline \multirow{2}{*}{ Treatments (I) } & \multirow{2}{*}{$\begin{array}{c}\text { Doses } \\
\left.\mathbf{d m}^{\mathbf{3}} \mathbf{h a}^{-\mathbf{1}}\right)\end{array}$} & \multicolumn{2}{c|}{ Cultivars (II) } & \multirow{2}{*}{ Mean } \\
\cline { 3 - 4 } & - & Satina & Tajfun & \\
\hline 1. Control - without UGmax & 1.0 & 3.44 & 3.47 & $3.46 \mathrm{c}$ \\
2. UGmax - before planting & 1.0 & 3.52 & 3.51 & $3.51 \mathrm{abc}$ \\
3. UGmax - before planting and double foliar & & 3.55 & $3.53 \mathrm{ab}$ \\
$\quad \begin{array}{l}\text { application } \\
\text { 4. UGmax - before planting and double foliar }\end{array}$ & 2.0 & 3.57 & 3.57 & 3.57 \\
$\quad \begin{array}{l}\text { application } \\
\text { 5. UGmax - double foliar treatment }\end{array}$ & 1.0 & 3.47 & 3.51 & $3.49 \mathrm{bc}$ \\
Mean & & $3.50 \mathrm{~b}$ & $3.52 \mathrm{a}$ & 3.51 \\
\hline
\end{tabular}

LSD at: 0.05 for: treatments $(\mathrm{I})=0.06$; cultivars (II) $=0.01$; interaction $(\mathrm{I} \times \mathrm{x}$ II) $=\mathrm{ns}$ ns - not significant

Table 7. Reducing sugars and sucrose content in potato tubers depending on UGmax and weather conditions ( $\mathrm{g} \mathrm{kg}^{-1}$ fresh matter) (mean of cultivars)

\begin{tabular}{l|c|c|c|c|c}
\hline \multirow{2}{*}{ Treatments (I) } & \multirow{2}{*}{$\begin{array}{c}\text { Doses } \\
\left(\mathbf{d m}^{\mathbf{3}} \mathbf{~ h a}^{-\mathbf{1}}\right)\end{array}$} & \multicolumn{3}{c|}{ Years (III) } & \multirow{2}{*}{ Mean } \\
\cline { 3 - 5 } & - & $\mathbf{2 0 0 8}$ & $\mathbf{2 0 0 9}$ & $\mathbf{2 0 1 0}$ & \\
\hline 1. Control - without UGmax & 1.0 & 3.45 & 3.74 & 3.18 & $3.46 \mathrm{c}$ \\
2. UGmax - before planting & 1.0 & 3.53 & 3.84 & 3.23 & $3.53 \mathrm{ab}$ \\
3. UGmax - before planting and & 2.0 & 3.55 & 3.90 & 3.27 & $3.57 \mathrm{a}$ \\
$\quad$ double foliar application & 1.0 & 3.47 & 3.79 & 3.22 & $3.49 \mathrm{bc}$ \\
4. UGmax - before planting and & & $3.50 \mathrm{~b}$ & $3.81 \mathrm{a}$ & $3.22 \mathrm{c}$ & 3.51 \\
$\quad$ double foliar application & & & & 3.22 & $3.51 \mathrm{abc}$ \\
5. UGmax - double foliar treatment & &
\end{tabular}

LSD at: 0.05 for: treatments $(\mathrm{I})=0.06$; years $(\mathrm{III})=0.18$; interaction $(\mathrm{I} x \mathrm{III})=\mathrm{ns}$ ns - not significant 
Cv. Tajfun accumulated more reducing sugars than Satina. The soil conditioner promoted an accumulation of reducing sugars, significant differences being detected for treatment 3 and 4, that is when UGmax had been applied three times. Under the weather conditions of 2010, the concentration of these sugars was the lowest and so the most favourable compared with the remaining study years. It was mainly due to the air temperature which was by 2.3 and $1.8^{\circ} \mathrm{C}$ higher towards the end of the growing season (July and August).

\section{Sucrose}

Sucrose content in potatoes was significantly affected by weather conditions in the study years (Tables 8, 9). The concentration of this disaccharide was the lowest in 2009 whereas in the remaining years it was significantly higher. Cultivars grown in the present study accumulated a similar amount of sucrose. An interaction of cultivars and soil conditioner application regime was found, which indicates a different response of the cultivars to spraying with UGmax. There was also observed an interaction of UGmax application regime and study years. The least sucrose was recorded in 2009 in tubers harvested from UGmax-treated plots which were sprayed three times at the rate of $2.0 \mathrm{dm}^{3} \mathrm{ha}^{-1}$.

Table 8. Sucrose content in potato tubers depending on UGmax and cultivars $\left(\mathrm{g} \mathrm{kg}^{-1}\right.$ fresh matter) (mean of years)

\begin{tabular}{l|c|c|c|c}
\hline \multirow{1}{*}{ Treatments (I) } & \multirow{2}{*}{$\begin{array}{c}\text { Doses } \\
\left(\mathbf{d m}^{\mathbf{3}} \mathbf{h a}^{-\mathbf{1}}\right)\end{array}$} & \multicolumn{2}{c|}{ Cultivars (II) } & \multirow{2}{*}{ Mean } \\
\cline { 3 - 4 } & - & $2.95 \mathrm{a}$ & $2.87 \mathrm{a}$ & 2.91 \\
\hline 1. Control - without UGmax & 1.0 & $2.89 \mathrm{~b}$ & $2.92 \mathrm{a}$ & 2.91 \\
2. UGmax - before planting & 1.0 & $2.90 \mathrm{ab}$ & $2.90 \mathrm{a}$ & 2.90 \\
$\begin{array}{l}\text { 3. UGmax - before planting and double foliar } \\
\quad \text { application }\end{array}$ & 2.0 & $2.89 \mathrm{~b}$ & $2.91 \mathrm{a}$ & 2.90 \\
$\begin{array}{l}\text { 4. UGmax - before planting and double foliar } \\
\quad \text { application }\end{array}$ & 1.0 & $2.92 \mathrm{ab}$ & $2.90 \mathrm{a}$ & 2.91 \\
5. UGmax - double foliar treatment & & $2.91 \mathrm{ab}$ & $2.90 \mathrm{a}$ & 2.91 \\
\hline
\end{tabular}

LSD at: 0.05 for: treatments $(\mathrm{I})=\mathrm{ns}$; cultivars $(\mathrm{II})=\mathrm{ns}$; interaction $(\mathrm{I} \times \mathrm{XI})=0.05$ ns - not significant

Table 9. Sucrose content in potato tubers depending on UGmax and weather conditions ( $g$ $\mathrm{kg}^{-1}$ fresh matter) (mean of cultivars)

\begin{tabular}{l|c|c|c|c|c}
\hline \multirow{2}{*}{ Treatments (I) } & \multirow{2}{*}{$\begin{array}{c}\text { Doses } \\
\left(\mathbf{d m}^{\mathbf{3}} \mathbf{h a}^{-\mathbf{1}}\right)\end{array}$} & \multicolumn{3}{c|}{ Years (III) } & \multirow{2}{*}{ Mean } \\
\cline { 3 - 5 } & - & $\mathbf{2 0 0 8}$ & $\mathbf{2 0 0 9}$ & $\mathbf{2 0 1 0}$ & \\
\hline 1. Control - without UGmax & 1.0 & $2.86 \mathrm{a}$ & $2.35 \mathrm{a}$ & $3.52 \mathrm{~b}$ & 2.91 \\
2. UGmax - before planting & 1.0 & $2.81 \mathrm{a}$ & $2.30 \mathrm{a}$ & $3.60 \mathrm{ab}$ & 2.90 \\
3. UGmax - before planting and double & & $2.33 \mathrm{a}$ & $3.58 \mathrm{ab}$ & 2.91 \\
$\quad$ foliar application & 2.0 & $2.81 \mathrm{a}$ & $2.27 \mathrm{a}$ & $3.63 \mathrm{a}$ & 2.90 \\
4. UGmax - before planting and double & 1.0 & $2.86 \mathrm{a}$ & $2.32 \mathrm{a}$ & $3.56 \mathrm{ab}$ & 2.91 \\
$\quad$ foliar application & & $2.83 \mathrm{~b}$ & $2.31 \mathrm{c}$ & $3.58 \mathrm{a}$ & 2.91 \\
5. UGmax - double foliar treatment & & &
\end{tabular}

LSD at: 0.05 for: treatments $(\mathrm{I})=\mathrm{ns}$; years $(\mathrm{III})=0.12$; interaction $(\mathrm{I} x \mathrm{III})=0.09$ ns - not significant 


\section{Discussion}

In potato production, the most important characteristics which determine fresh tuber consumption suitability and processability include: dry matter content, total sugars (glucose + fructose + sucrose) and reducing sugars (glucose + fructose) which are also called simple sugars. Tubers ought to contain $18-22 \%$ dry matter and up to $1 \%$ total sugars (when this level, is exceeded, tubers taste sweet) (Lisińska et al., 2009). The results of the research showed that the total sugar content depended only on weather conditions. Total sugars and sucrose content were the highest in tubers harvested in 2010 when both precipitation and temperature during the growing period were the highest, the lowest values for both the traits being recorded in 2009 when precipitation was the lowest. A similar response of tubers to weather conditions, in terms of total sugar accumulation, was observed by other authors (Sawicka and Pszczółkowski, 2005; Zarzecka and Gugała, 2009). Cultivars (Satina and Tajfun) grown in the experiment discussed here contained similar amounts of total sugars, which is consistent with results reported by other workers (Gugała et al., 2013) although Bhattacharjee et al. (2014) found significant differences between cultivars being compared as to their tuber content of total sugars. There is no published literature concerning the effect of UGmax on total sugars, reducing sugars or sucrose in potato tubers.

The concentration of reducing sugars in the tubers of potato for processing for foodstuffs is one of the most important qualitative characteristics, and also called a priority. As a result of long-term studies conducted in Poland and worldwide (Coop et al., 2000; Lisińska et al., 2009; Zgórska, 2013; Grudzińska et al., 2014), the following baseline and optimal concentrations of reducing sugars in potato tuber fresh matter have been determined: not more than $0.25 \%$ (optimum level: up to $0.15 \%$ ) for potatoes destined for chips production, not more than $0.50 \%$ (optimum level: up to $0.25 \%$ ) for French fries varieties, and not more than $0.50 \%$ (optimum level: up to $0.25 \%$ ) for dried products and fresh consumption. Tubers of potato which contain increased amounts of reducing sugars (glucose and fructose) turn brown when heated. In the present studies, reducing sugars content depended significantly on the cultivar, soil conditioner UGmax application and moist-thermal conditions during potato vegetation. The effect of potato cultivar on this characteristic was reported by other authors (Abong et al., 2009; Bhattacharjee et al., 2014; Grudzińska et al., 2014). On the contrary, Sawicka and Pszczółkowski (2005), Gugała et al. (2013) found no such influence. Grudzińska et al. (2014) reported that reducing sugar content was primarily affected by the air temperature 10 days before potato harvest. Moreover, the authors (Grudzińska et al., 2014) found, based on correlation coefficients which they had calculated, that the higher temperature was observed 10-20 days before harvest, the lower concentration of reducing sugars was recorded. A statistically significant effect of hydrothermal conditions on an accumulation of reducing sugars was also noted by other authors (Gugała et al., 2013; Brazinskiene et al., 2014). Cultivars grown in the present study accumulated similar amount of sucrose as in the findings reported by other authors (Sawicka and Pszczółkowski, 2005; Brazinskiene et al., 2014; Czerko et al., 2016).

Many authors have shown that the UGmax soil conditioner had a desirable, beneficial effect on the total and commercial yield of potato tubers, tuber weight per potato (Trawczyński and Bogdanowicz, 2007; Kowalska, 2016; Zarzecka and Gugała, 2016), increased starch and vitamin $C$ content (Zarzecka et al., 2018) and improved soil chemical properties (Trawczyński and Bogdanowicz, 2007, Dębska et al., 2016) as compared to the control. 


\section{Conclusion}

The application of soil conditioner UGmax significantly increased the content only of reducing sugars in potato tubers, whereas the total sugars and sucrose content did not change. However, the largest, significant influence on the content of carbohydrates (total sugars, reducing sugars, sucrose) had weather conditions during the years of research. The cultivars grown in this experiment can be used in direct consumption, for dried products and for processing into French fries and soil conditioner UGmax used did not cause adverse changes in the chemical composition of tubers.

\section{REFERENCES}

[1] Abong, G. O., Okoth, M. W., Karuri, E. G., Kabira, J. N., Mathooko, F. M. (2009): Levels of reducing sugars in eight Kenyan potato cultivars as influenced by storage of maturity and storage conditions. - J. Anim. and Plant Sci. 2: 76-84.

[2] Andre, C. H., Legay, M. S., Iammarino, C. H., Ziebel, J., Guignard, C., Larondelle, Y., Hausman, J. F., Evers, D., Miranda, L. M. (2014): The Potato in the Human Diet: a Complex Matrix with Potential Health Benefits. - Potato Res. 57: 201-214.

[3] Bhattacharjee, A., Roy, T. S., Haque, M. N., Pulok, M. A. I., Rahman, M. M. (2014): Changes of sugar and starch levels in ambient stored potato derived from TPS. - Int. J. Sci. Res. Publ. 4: 1-5.

[4] Brazinskiene, V., Asakaviciute, R., Miezeliene, A., Alencikiene, G., Ivanauskas, L., Jakstas, V., Viskeli, P., Razukas, A. (2014): Effect of farming systems on the yield, quality parameters and sensory properties of conventionally and organically grown potato (Solanum tuberosum L.) tubers. - Food Chemistry 145: 903-909.

[5] Camire, M. E., Kubow, S., Donnelly, D. J. (2009): Potatoes and human health. - Crit. Rev. Food Sci. Nutr. 49: 823-840.

[6] Coop, L. J., Blenkinsop, R. W., Yada, R. Y., Marangoni, A. G. (2000): The relationship between respiration and chip colour during long-term storage of potato tubers. - Am. J. Potato Res. 77: 279-287.

[7] Czerko, Z., Wierzbicka, A., Borowska-Komenda, M. (2016): Changes in the content of reducing sugars and sucrose in tubers of 11 potato cultivars during long term storage at 5 and $8^{\circ} \mathrm{C}$. - Acta Agroph. 23: 31-38. (in Polish).

[8] Dębska, B., Długosz, J., Piotrowska-Długosz, A., Banach-Szott, M. (2016): The impact of a bio-fertilizer on the soil organic matter status and carbon sequestration-results from a field-scale study. - J. Soils Sediments 16: 335-343.

[9] Dinesh, R., Srinivasan, V., Hamza, S., Manjusha, A. (2010): Short-term incorporation of organic manures and biofertilizers influences biochemical and microbial characteristics of soils under an annual crop [Turmeric (Curcuma longa L.)]. - Bioresour Technol. 101: 4697-4702.

[10] Grudzińska, M., Zgórska, K., Czerko, Z. (2014): Impact of weather conditions on the content of reducing sugars in potato tubers. - Zeszyty Problemowe Postępów Nauk Rolniczych 577: 43-52. (in Polish).

[11] Gugała, M., Zarzecka, K., Sikorska, A., Dołęga, H. (2013): Changes in sugar content in cultivars potato tubers depending on the weed control methods. - Prog. Plant Prot. 53: 271-275. (in Polish).

[12] Kaczmarek, Z., Jakubus, M., Grzelak, M., Mrugalska, L. (2008): Impact of the addition of various doses of effective microorganisms to arable humus horizons of mineral soils on their physical and water properties. - J. Res. Appl. Agric. Eng. 53: 118-121. (in Polish).

[13] King, J. C., Slavin, J. L. (2013): White Potatoes, Human Health, and Dietary Guidance. Adv. Nutr. 4: 393S-401S. 
[14] Kołodziejczyk, M. (2014): Effectiveness of nitrogen fertilization and application of microbial preparations in potato cultivation. - Turk. J. Agric. For. 38: 299-310.

[15] Kowalska, J. (2016): Effect of fertilization and microbiological bio-stimulators on healthiness and yield of organic potato. - Prog. Plant Prot. 56: 230-235. (in Polish).

[16] Krełowska-Kułas, M. (1993): Test the quality of food products. - State ed. Economical, Warsaw, Poland, p. 53-55. (in Polish).

[17] Lisińska, G., Pęksa, A., Kita, A., Rytel, E., Tajner-Czopek, A. (2009): The quality of potato for processing and consumption. - Food 3 (Special Issue 2): 99-104.

[18] Malero, S., Porra, J. C. R., Herencia, J. F., Madejón, E. (2006): Chemical and biochemical properties in a silty loam soil under conventional and organic management. Soil Tillage Res. 90: 162-170.

[19] Marcinek, J., Komisarek, J. (2011): Classification of soils in Poland. - Roczniki Gleboznawcze 62: 1-193. (in Polish).

[20] Mrówczyński, M., Roth, M. (2009): Sustainable use of plant protection products. Problemy Inżynierii Rolniczej 2: 93-97. (in Polish).

[21] Ozturk, E., Polat, T. (2016): The effect of long term storage on physical and chemical properties of potato. - Turk. J. Field Crops 21: 218-223.

[22] Piotrowska, A., Długosz, J., Zamorski, R., Bogdanowicz, P. (2012): Changes in some biological and chemical properties of an arable soil treated with the microbial biofertilizer UGmax. - Pol. J. Environ. Stud. 21: 455-463.

[23] Pobereżny, J., Wszelaczyńska, E., Wichrowska, D., Jaskulski, D. (2015): Content of nitrates in potato tubers depending on the organic matter, soil fertilizer, cultivation simplifications applied and storage. - Chilean J. Agric. Res. 75: 42-49.

[24] Sawicka, B., Pszczółkowski, P. (2005): Dry matter and carbohydrates content in the tubers of very early potato varieties cultivated under coverage. - Acta Sci. Pol. Hortorum Cultus 4: 111-122.

[25] Slavin, J. L. (2013): Carbohydrates, dietary fiber, and resistant starch in white vegetables: links to health outcomes. - Adv. Nutr. 4: 351S-355S.

[26] Trawczyński, C. (2007): Utilization of soil fertilizer in potato cultivation. - Ziemniak Polski 3: 6-29. (in Polish).

[27] Trawczyński, C., Bogdanowicz, P. (2007): Utilization of soil fertilizer in ecological aspect of potato cultivation. - J. Res. Appl. Agric. Eng. 52: 94-97. (in Polish).

[28] Zarzecka, K., Gugała, M. (2009): Changes in the content of total sugars present in potato tubers depending on the agrotechnical treatment. - Roczniki Państwowego Zakładu Higieny 60: 337-340. (in Polish).

[29] Zarzecka, K., Gugała, M. (2013): Performance of one potato plant as influenced by soil conditioner UGmax. - J. Ecol. Eng. 14: 45-49.

[30] Zarzecka, K., Gugała, M., Sikorska, A., Mystkowska, I. (2018): The impact of the soil conditioner UGmax on selected qualitative characteristics of potato tubers. - Appl. Ecol. Envir. Res. 16(1): 39-50.

[31] Zgórska, K. (2013): Use of potatoes for food and industrial purposes. - Inżynieria Przetwórstwa Spożywczego 3/4: 5-9. (in Polish). 